\title{
ANALISIS STILISTIKA DAN NILAI PENDIDIKAN KARAKTER KUMPULAN PUISI PERIHAL GENDIS SERTA PEMANFAATANNYA DALAM PEMBELAJARAN SASTRA
}

\author{
Mar'atul Dini Lathif Mahmudah, Herman J. Waluyo, Kundharu Saddhono \\ Universitas Sebelas Maret \\ Email: dinilatif@gmail.com
}

\begin{abstract}
Abstrak: Penelitian ini bertujuan untuk mendeskripsikan dan menjelaskan (1) diksi dalam buku kumpulan puisi Perihal Gendis karya Sapardi Djoko Damono; (2) bahasa figuratif dalam buku kumpulan puisi Perihal Gendis karya Sapardi Djoko Damono; (3) citraan dalam buku kumpulan puisi Perihal Gendis karya Sapardi Djoko Damono; (4) nilai-nilai pendidikan karakter dalam buku kumpulan puisi Perihal Gendis karya Sapardi Djoko Damono; dan (5) relevansi stilistika buku kumpulan puisi Perihal Gendis karya Sapardi Djoko Damono sebagai bahan ajar menulis puisi di Sekolah Menengah Atas. Penelitian ini merupakan penelitian kualitatif yang menggunakan metode content analysis dengan kajian stilistika. Sumber data penelitian ini adalah buku kumpulan puisi Perihal Gendis karya Sapardi Djoko Damono yang diterbitkan Gramedia Pustaka Utama. Teknik pengumpulan data yang digunakan yaitu dengan motede analisis isi. Validasi data yang digunakan yaitu triangulasi sumber data dan teori. Hasil penelitian sebagai berikut: (1) Diksi bermakna konotatif lebih dominan daripada denotatif; (2) Terdapat 3 majas yang paling dominan, anafora, personifikasi, dan simbolik (3) Citraan yang paling dominan adalah citraan gerak, penglihatan, dan pendengaran; (4) Nilai pendidikan karakter yang paling dominan adalah rasa ingin tahu; (5) Novel ini dapat dipertimbangkan sebagai bahan ajar menulis puisi di Sekolah Menengah Atas.
\end{abstract}

Kata kunci: stilistika, nilai pendidikan karakter, kumpulan puisi Perihal Gendis, pembelajaran menulis puisi, sekolah menengah atas

\section{STYLISTIC AND CHARACTER EDUCATION VALUES ANALYSIS OF “PERIHAL GENDIS" POEMS COLLECTIONS AND ITS UTILIZATION IN LITERATURE LEARNING}

\begin{abstract}
This research study aims to describe and explain (1) the diction of poems collection entitled Perihal Gendis by Sapardi Djoko Damono; (2) the figurative language of poems collection entitled Perihal Gendis by Sapardi Djoko Damono; (3) the imagery of poems collection entitled Perihal Gendis by Sapardi Djoko Damono; (4) character education values of poems collection entitled Perihal Gendis by Sapardi Djoko Damono; and (5) the stylistic relevance of poems collection entitled Perihal Gendis by Sapardi Djoko Damono by learning to write poems in Senior High School.This research used a qualitative descpriptive method literature with content analysis. The source of data of this study is poems book and collection entittled Perihal Gendis by Sapardi Djoko Damono published by Gramedia Pustaka Utama. This technique is content analysis method. The data validation used in this study is triangulation source of data and theory. The results of this study as follows : (1) the connotative meanings of diction are more dominant than denotative; (2) the figurative languages are found out that the top three most dominant are Anaphora then Personification. The simbolik; (3) the use of varied imageries are found out that the dominant imagery is motion image; (4) The most dominant value of character education is curiosity; (5) This poems book and collection can be evaluated to poetry writing materials in Senior High School.
\end{abstract}

Keywords: stylistic, character education values, Perihal Gendis poems collections, writing poems learning, senior high school.

BASASTRA Jurnal Bahasa, Sastra, dan Pengajarannya

Volume 8 Nomor 1, April 2020, P-ISSN 2302-6405, E-ISSN 2714-9765 


\section{PENDAHULUAN}

Puisi adalah karya sastra yang menggunakan bahasa yang dipadatkan, dipersingkat, dan diberi rima dengan bunyi yang padu dan dengan menggunakan katakata yang tidak sebenarnya (kata kias) Waluyo (2003: 1-2). Pradopo (2010: 6-7) berpendapat bahwa "Puisi adalah mengekspresikan pemikiran, membangkitkan perasaan, dan merangsang imajinasi dengan menggunakan rima yang tersusun.” Kosasih (2015: 206-207) mengungkapkan bahwa puisi adalah karya sastra yang menggunakan kata-kata kias, indah, dan penuh dengan makna yang terkandung di dalamnya. Keindahan yang dimaksud disebabkan oleh penggunakan diksi, bahasa figuratif, citraan, rima, dan irama.

Materi pembelajaran yang diterapkan dalam pembelajaran Bahasa Indonesia pada Kurikulum 2013 salah satunya adalah puisi. Penelitian ini mengkaji kumpulan puisi Perihal Gendis karya Sapardi Djoko Damono. Sapardi Djoko Damono merupakan pujangga Indonesia yang terkemuka dan dikenal lewat berbagai puisi-puisinya yang menggunakan kata-kata sederhana sehingga beberapa diantaranya sangat populer. Karya beliau antara lain adalah Hujan Bulan Juni, Yang Fana adalah Waktu, Duka-Mu Abadi, Bilang Begini, Maksudnya Begitu, Manuskrip Sajak Sapardi, Perihal Gendis, dan lain-lain.

Perihal Gendis Merupakan karya beliau yang paling baru terbit pada bulan Oktober tahun 2018. Kumpulan puisi Perihal Gendis berisikan 15 puisi panjang yang sebagian isinya mengisahkan Gendis, yaitu gadis remaja beranjak dewasa yang berteman dengan sepi dan berdialog dengan apapun yang ada di dekatnya. Selain itu, Perihal Gendis juga bercerita tentang waktu, kematian dengan cara yang indah, dan pencarian jati diri.
Pengarang dalam membuat tulisannya memiliki kekhasan dan keunikan yang dituangkan dalam tiap bahasa. Kekhasan dan keunikan sebuah karya sastra dapat diteliti dapat menandakan dan menemukan ciri secara umum karya seorang penyair maupun penulis. Ilmu yang tepat untuk mengkaji penggunaan bahasa dalam karya sastra dengan dengan pendekatan linguistik adalah kajian stilistika. Menurut Satoto (2012:34) stilistika adalah 'style', 'stail', atau 'gaya', yaitu cara khas yang digunakan seseorang untuk untuk mengungkapkan diri pribadi seseorang. Sejalan dengann pendapat yang dipaparkan oleh Ratna (2013: 3) bahwa "stilistika adalah Ilmu tentang gaya, sedangkan stil (style) secara umum dibicarakan secara luas adalah cara khas yang diungkapkan dengan cara tertentu sehingga tujuan yang dimaksudkan dapat dicapai secara maksimal.”. Sehingga ciri khas seseorang dalam karyanya dapat dilihat dari gaya bahasa, diksi, dan citraan yang digunakan dalam karya tersebut.

Berdasarkan pengamatan setelah membaca kumpulan puisi Perihal Gendis banyak ditemukan penggunan bahasa yang unik, sederhana, sopan, lembut dan apik, dan menggunakan kalimat yang pendekpendek sehingga dapat menjadi daya tarik siswa. Namun, walaupun menggunakan kalimat sehari-hari pembaca merasa kesulitan untuk menemukan makna apa yang ingin disampaikan oleh penulis. Pembaca harus membaca puisi tersebut setidaknya 2-3 kali untuk memahami makna apa yang ingin disampakan oleh penulis. Oleh karena itu, dilakukan telaah terhadap stilistika dengan batasan diksi, gaya bahasa, dan citraan.

Telaah mengenai diksi, bahasa figuratif, dan citraan penting dilakukan khususnya bagi siswa untuk memudahkan siswa dalam menciptakan puisi karena akan memperkaya kosa kata yang dimiliki.

BASASTRA Jurnal Bahasa, Sastra, dan Pengajarannya 
Kemampuan menulis puisi siswa akan sesuai dengan kemampuannya dalam memahami dan menguasai diksi, bahasa figuratif, dan citraan. Jika siswa dapat memahami dan menguasai stilistika dengan baik, maka siswa dapat memahami makna mendalam pesan yang ingin disampaikan oleh penulis.

Selain mengkaji stilistika, penelitian ini juga mengaji mengenai pendidikan karakter yang terkandung dalam puisi. Pendidikan karakter penting karena sesuai dengan amanat kurikulum 2013 yang berbasis pendidikan karakter dalam setiap mata pelajaran yang diajarkan, baik disampaikan secara langsung maupun disisipkan dalam pembelajaran. Penting bagi guru untuk memilih bahan ajar yang mengandung nilai pendidikan karakter agar nilai yang terdapat dalam bahan ajar dapat memberikan pembelajaran bagi siswa.

Penelitian ini sejalan dengan penelitian yang di dilakukan oleh Widya Yuni Lestari, Sumarwati, dan Yant Mujiyanto (2017), dosen Program Bahasa dan Sastra Indonesia Fakultas Keguruan dan Ilmu Pendidikan Universitas Sebelas Maret dengan judul "Analisis Stilistika Kumpulan Puisi Asal Muasal Pelukan Karya Candra Malik Sebagai Materi Ajar Bahasa Indonesia di Sekolah Menengah Atas" yang meneliti stilistika mengenai diksi, gaya bahasa, dan citraan. Kebaruan dalam penelitian ini adalah menambahkan bahasa figuratif dan nilai pendidikan karakter kedalam rumusan masalah dan bahasan.

Sehubungan dengan pemaparan diatas, peneliti tertarik untuk mengetahui mengenai pilihan kata atau diksi, gaya bahasa, dan citraan yang terkandung dalam kumpulan puisi Perihal Gendis karya Sapardi Djoko Damono. Selain itu, peneliti tertarik untuk merelevansikan buku kumpulan puisi ini sebagai bahan ajar menulis puisi di SMA dengan KD. Dari uraian di atas, peneliti memutuskan untuk mengambil judul "Kajian Stilistika Kumpulan Puisi Perihal Gendis Karya
Sapardi Djoko Damono dan Relevansinya Sebagai Bahan Ajar Menulis Puisi di Sekolah Menengah Atas".

Rumusan masalah pada penelitian ini adalah (1) Bagaimanakah jenis pilihan kata yang terdapat dalam kumpulan puisi Perihal Gendis karya Sapardi Djoko Damono? (2) Bagaimanakah jenis bahasa figuratif yang digunakan dalam buku kumpulan Puisi Perihal Gendis karya Sapardi Djoko Damono? (3) Bagaimanakah citraan yang digunakan dalam buku kumpulan puisi Perihal Gendis karya Sapardi Djoko Damono? (4) Bagaimanakah nilai pendidikan karakter yang terkandung dalam buku kumpulan puisi Perihal Gendis karya Sapardi Djoko Damono, dan (5) Bagaimanakah relevansi antara buku kumpulan puisi Perihal Gendis karya Sapardi Djoko Damono dengan pembelajaran menulis puisi siswa di Sekolah Menengah Atas?

\section{METODE PENELITIAN}

Jenis penelitian ini adalah penelitian kualitatif. Penelitian kualitatif kali ini bersifat content analysis (analisis isi) dengan sumber data utama buku kumpulan puisi Perihal Gendis karya Sapardi Djoko Damono. Teknik pengambilan sampel dengan purposive sampling. Penelitian ini menggunakan triangulasi sumber data dan teori.

\section{HASIL DAN PEMBAHASAN}

Dalam hasil penelitian ini akan mendeskripsikan mengenai pemerolehan hasil dari penelitian yang telah dilakukan. Hasil penelitian tersebut meliputi diksi yang terdapat dalam buku kumpulan puisi Perihal Gendis karya Sapardi Djoko Damono, bahasa figratif yang terdapat dalam buku kumpulan puisi Perihal Gendis karya Sapardi Djoko Damono, citraan yang terdapat dalam buku kumpulan puisi Perihal Gendis karya Sapardi Djoko Damono, nilai pendidikan karakter yang terdapat dalam buku kumpulan puisi Perihal Gendis karya Sapardi Djoko 
Damono, dan relevansi buku kumpulan puisi Perihal Gendis sebagai bahan ajar menulis puisi di Sekolah Menengah Atas.

\section{Diksi dalam Buku Kumpulan Puisi Perihal Gendis Karya Sapardi Djoko Damono}

Kumpulan puisi Perihal Gendis karya Sapardi Djoko Damono yang dianalisis melalui pendekatan stilistika, yaitu puisi Percakapan di Luar Suara Riuh, Hening Gendis, Duduk di Teras Belakang Rumah Waktu Bulan Purnama, Langit-langit, Konon, dan Tak Perlu. Puisi-puisi tersebut dikaji melalui pendekatan stilistika dengan aspek kebahasaan meliputi diksi, bahasa figuratif, dan citraan. Menurut Keraf (2004: 27-29), diksi menurut maknanya dibedakan menjadi dua, yaitu diksi denotatif dan konotatif. Analisis data selengkapnya dapat dilihat dari paparan berikut ini:

Puisi Percakapan di Luar Suara Riuh memiliki penggunaan diksi denotatif dan konotatif yang dapat dijelaskan sebagai berikut.

\section{Makna Denotatif Puisi Percakapan di Luar Suara Riuh}

Terdapat 6 makna denotatif dalam Puisi Percakapan di Luar Suara Riuh, diantaranya adalah:

\footnotetext{
"Kupu-kupu dimana selama ini kau gerangan? Sudah sekian lama aku tidak melihatmu berpasangan ke sana ke mari di taman ini." (Perihal Gendis: 1).
}

Data di atas merupakan kata-kata denotatif karena menggunakan kata yang konkret. Dalam puisi tersebut jelas bahwa penyair lewat tokoh Gendis menanyakan keberadaan kupu-kupu tanpa ada makna lain yang terkandung. Selain itu, Gendis menanyakan pasangan kupu-kupu dengan maksud jelas tanpa tersirat makna lain.

Makna Konotatif Puisi Percakapan di Luar Suara Riuh

Terdapat 9 makna konotatif dalam Puisi Percakapan di Luar Suara Riuh diantaranya adalah:
"Bagaimana pula kau meramu aroma merah hijau biru kuning itu?" (Perihal Gendis: 2)

Aroma tidak bisa diibaratkan dengan warna merah hijau biru kuning. Merah hijau biru kuning merupakan jenis warna yang dapat diibaratkan dengan aroma yang bermacam-macam wanginya. Kata tersebut dipilih untuk menimbulkan sosok keindahan dan menggambarkan wangi mawar yang bermacam-macam. Oleh karena itu, data diatas merupakan makna konotatif.

Puisi Hening Gendis memiliki penggunaan diksi denotatif dan konotatif yang dapat dijelaskan sebagai berikut:

\section{Makna Denotatif Puisi Hening Gendis}

Terdapat 1 makna denotatif dalam Puisi Hening Gendis, diantaranya adalah:

"Agar kau berpikir akan ada yang menepatinya pada suatu hari nanti "(Perihal Gendis: 18)

Data diatas menggunakan kata konkret untuk menyampaikan gagasan bahwa akan ada seseorang yang menepati janjinya kepada Gendis suatu hari nanti. Data tersebut menggunakan kata konkret sehingga tidak menimbulkan makna lain.

\section{Makna Konotatif Puisi Hening Gendis}

Terdapat 14 makna denotatif dalam Puisi Hening Gendis, diantaranya adalah:

"Hening adalah ketika angin membujukku mendirikan istana di atas selembar awan putih, selembar saja berlayar sangat perlahan mengayuh angin yang tak henti-hentinya merindukan istana agar bisa sejenak, ya sejenak saja terlentang meluruskan badan melupakan mimp tentang istana, tentang istirahat tentang takdir sebagai kembara abadi." (Perihal Gendis: 12)

Data diatas menggunakan makna konotatif yang menggambarkan suasana keheningan dalam suatu malam. Dalam sebuah keheningan, Gendis sedang melamun memikirkan banyak hal. "Telentang meluruskan badan" menggamarkan Gendis yang sedang telentang sebelum tidur lalu melamunkan banyak hal. Penyair menggunakan simbol

BASASTRA Jurnal Bahasa, Sastra, dan Pengajarannya 
awan, angin, dan istana untuk menjelaskan lamunan yang berada dalam pikiran Gendis untuk memberikan kesan keindahan pada puisi yang ditulis.

Puisi Duduk di Teras Belakang Rumah memiliki penggunaan diksi denotatif dan konotatif yang dapat dijelaskan sebagai berikut:

\section{Makna Denotatif Puisi Duduk di Teras Belakang Rumah}

Terdapat 2 makna denotatif dalam Puisi Duduk di Teras Belakang Rumah, diantaranya adalah:

"Gendis megangguk memejamkan matanya." (Perihal Gendis: 20)

Data diatas menggunakan makna denotatif karena menggunakan bahasa yang jelas untuk menggambarkan posisi Gendis yang sedang mengangguk dan memejamkan mata. Bahasa disampaikan oleh penyair dengan jelas tanpa menimbulan makna lain. Gendis merenung dengan memejamka mata dan mengangguk karena bulan tidak menjawab pertanyaan yang diajukan oleh Gendis.

\section{Makna Konotatif Puisi Duduk di Teras Belakang Rumah}

Terdapat 3 makna Konotatif dalam Puisi Duduk di Teras Belakang Rumah, diantaranya adalah:

\begin{abstract}
"Bulan sangat letih meski putih tetap menyiarkan keelokannya. Kenapa kau begitu pucat bulan? Bulan yang selamanya bisu seperti menahan suara yangn cakrawala batasnya tiba-tiba saja menjelma gerimis. Butir-butir cahaya adalah gerimis taburan kristal yang tersangkut di rerumputan dan pohonan perdu dan pohon rambat di tembok; dan seluruh halaman menjelma samudra menjelma langit kristal menjelma suara-suara kristal. Apa gerangan yang membebanimu bulan? Jawabannya tanpa bahasa." (Perihal Gendis: 20)
\end{abstract}

Data diatas banyak menggunaka kata-kata konotatif. Penggunaan konotatif dalam puisi diatas untuk menggambarkan bulan purnama pada malam hari dan Gendis yang sedang duduk di depan kesepian sehingga mengajak bicara bulan.
"Bulan sangat letih meski putih tetap menyiarkan keelokannya" menandakan bahwa keadaan malam yanng terdapat bulan purnama. Namun, bulan tidak bisa menjawab pertanyaan Gendis karena bulan merupakan makhluk tak bernyawa. Hal tersebut terdapat pada kalimat "Bulan yang selamanya bisu seperti menahan suara...".

Puisi Konon memiliki penggunaan diksi denotatif dan konotatif yang dapat dijelaskan sebagai berikut:

\section{Makna Denotatif Puisi Konon}

Terdapat 1 makna denotatif dalam Puisi Konon, diantaranya adalah:

"Oke, aku berpihak padamu kalau begitu karena kau tak lain adalah aku." (Perihal Gendis: 38)

Data diatas menggunakan kata-kata konkret. "Karena kau tak lain adalah aku" menunjukkan dengan jelas bahwa Gendis berbicara dalam hati dengan dirinya sendiri tanpa menimbulkan makna lain.

\section{Makna Konotatif Puisi Konon}

Terdapat 4 makna denotatif dalam Puisi Konon, diantaranya adalah:

"Konon kasih sayang itu persis bola pimpong yang kuning yang putih dismes siang malam melewati net dipelintir siang malam menyentuh pinggir meja dan menggelinding di lantai dan penyot kena injak. Ia ingin jadi buah apel yang krowak. Tapi ada sebilah pisau di sebelahmu." (Perihal Gendis: 35)

Data diatas banyak menggunakan kata-kata konotatif yang menggambarkan kasih sayang yang sempurna dan indah pada awalnya namun akan rusak pada akhirnya. Kesempurnaan cinta diibaratkan dengan bola pimpong yang bulat dan utuh. Kasih sayang yang hancur digambarkan dengan frasa "dan menggelinding di lantai dan penyot kena injak. Karena kekeh, penyair tetap memperlihatkan kasih sayang yang indah dengan ingin menjadi buah apel yang krowak. Namun pada akhir puisi penggunaan kalimat Tapi ada sebilah pisau di sebelahmu menguatkan bahwa walaupun apel tersebut krowak tetap akan

BASASTRA Jurnal Bahasa, Sastra, dan Pengajarannya 
bisa hancur dengan sebilah pisau yang ada disebelahnya.

Puisi Langit-langit memiliki penggunaan diksi denotatif dan konotatif yang dapat dijelaskan sebagai berikut:

\section{Makna Denotatif Puisi Langit-langit}

Terdapat 1 makna denotatif dalam Puisi Langit-langit, diantaranya adalah:

"Untuk apa pula aku meninggalkanmu, rumah? Disinipun aku bisa menangis, bukan? sekarang pun aku bisa menangis, bukan? Sekarang pun aku sedang menagis, bukan" (Perihal Gendis: 51)

Terdapat penggunaa kata-kata konkret dalam puisi diatas. Penggunaan huruf miring oleh penyair menggambarkan konflik batin tokoh. Gendis terlihat merasa menyesal karena sempat berpikir untuk meninggalkan rumah. Dia merasa bisa menangis dan bersedih tanpa harus meninggalkan rumah.

\section{Makna Konotatif Puisi Langit-langit}

Terdapat 11 makna konotatif dalam Puisi Langit-langit, diantaranya adalah:

Layar televisi itu bergeser ke sebuah dinding otaknya yang kadang-kadang dibandingkanya dengan satu-satunya lapangan bola yang tidak jauh dari kompleks: rumput tidak rata, bencahbencah air yagn sudah kering, gawang yang patah sebelah tiangnya, da jerit anak-anak yang keluar masuk dunia dongeng yang suka dibacanya di buku komik ketika dulu mulai belajar membaca. Untuk apa pula waktu itu aku mau meninggalkanmu, rumah?" (Perihal Gendis: 45)

Data diatas dapat dikategorikan sebagai makna konotatif karena menggunakan makna kiasan atau tidak sebenarnya. Puisi tersebut menggambarkan Gendis yang masih membayangkan hal-hal yang ada disekitarnyan dengan kondisi lapangan bola yang ada di dekat rumahnya. Gendis membayangkan banyak hal dan merasa menyesal dulu pernah ingin pergi dari rumah. Hal tersebut ditunjukkan dalam kalimat akhir puisi tersebut Untuk apa pula waktu itu aku mau meninggalkanmu, rumah.
Puisi Tak Perlu memiliki penggunaan diksi denotatif dan konotatif yang dapat dijelaskan sebagai berikut:

\section{Makna Denotatif Puisi Tak Perlu}

Terdapat 1 makna denotatif dalam Puisi Tak Perlu, diantaranya adalah:

"Tidak perlu menjadi risau. Tidak perlu sama sekali." (Perihal Gendis: 55)

Data diatas menggunakan bahasa konkret. Gendis digambarkan pasrah dan tidak mengkhawatirkan ayah dan ibunya yang sudah berpisah. Hal tersebut dipertegas dengan kalimat "Tidak perlu sama sekali".

\section{Makna Konotatif Puisi Tak Perlu}

Terdapat 2 makna konotatif dalam Puisi Tak Perlu, diantaranya adalah:

"Barangkali tidak perlu mencari tahu dan menjadi risau kenapa Ayah ke Selatan dan Ibu ke Utara." (Perihal Gendis: 55)

Data diatas menggunakan makna konotatif. Gendis merasa tidak perlu khawatir dan bertanya-tanya mengapa ayah dan ibunya berpisah. Selatan dan utara menunjukka dua arah yang berbeda yang memiliki arti berpisah atau bercerai.

\section{Bahasa Figuratif dalam Buku Kumpulan Puisi Perihal Gendis Karya Sapardi Djoko Damono \\ Kumpulan puisi Perihal Gendis} karya Sapardi Djoko Damono yang dianalisis melalui pendekatan stilistika, yaitu puisi Percakapan di Luar Suara Riuh, Hening Gendis, Duduk di Teras Belakang Rumah Waktu Bulan Purnama, Langit-langit, Konon, dan Tak Perlu. Puisi-puisi tersebut dikaji melalui pendekatan stilistika dengan aspek kebahasaan meliputi diksi, bahasa figuratif, dan citraan. Menurut Waluyo (1955: 8390) bahasa figuratif dibedakan menjadi dua, yaitu kiasan (gaya bahasa) dan lambang benda. Berikut adalah penjelasan majas yang ditemukan dalam masingmasing puisi:

Pada puisi Percakapan di Luar Suara Riuh menggunkan majas yang bervariasi. 
Beberapa majas yang digunakan adalah pararima, metafora, personifikasi, anafora, epifora, aferesis, mesodiplosis, pleonasme, retoris, dan simbolik. Berikut adalah penjelasan mengenai majas yang terdapat dalam puisi Percakapan di Luar Suara Riuh:

\section{Majas Penegasan}

Beberapa majas penegasan yang digunakan pada puisi Percakapan di Luar Suara Riuh, salah satunya adalah yaitu majas pararima:

"Sudah sekian lama aku tidak melihatmu terbang berpasangan $k e$ sana ke mari" (Perihal Gendis: 1)

Data diatas termasuk dalam majas penegasan berupa pararima. Hal tersebut karena terdapat perulangan kata konsonan awal dan akhir dalam puisi tersebut. Kata tersebut yaitu ke sana ke mari. Gendis lama tidak melihat kupu-kupu terbang ke sana ke mari.

\section{Majas Perbandingan}

Beberapa majas perbandingan yang digunakan pada puisi Percakapan di Luar Suara Riuh, salah satunya adalah yaitu majas metafora:

"Rumahku ada di sela-sela bunga mawar yang seluas aroma senatiasa terbuka." (Perihal Gendis:1)

Data diatas merupakan majas metafora karena terdapat kata seluas aroma. Seluas aroma mempunyai arti aromanya yang sangat harum yang disamakan dengan aroma mawar. Penyair membandingkan aroma mawar yang sangat harum dengan rumah yang luas.

Puisi Hening Gendis menggunakan majas yang bervariasi. Beberapa majas yang digunakan adalah anafora, epifora, retoris, aferesis, personifikasi, onomatope, hiperbola, dan simbolik. Berikut adalah penjelasan mengenai majas yang terdapat dalam puisi Hening Gendis:

\section{Majas Penegasan}

Beberapa majas penegasan yang digunakan pada puisi Hening Gendis, salah satunya adalah yaitu majas anafora:

".........melupakan impian

tentang istana

tentang istirahat tentang takdir." (Perihal

Gendis: 12)

Data diatas termasuk dalam majas anafora. Penyair mengulang kata "tentang" yang letaknya pada awal kalimat pada baris ke 3, 4, dan 5. Penggunaa kata tentang digunakan penyair untuk mempertegas tentang hal-hal yangn harus dilupakan oleh Gendis.

\section{Majas Perbandingan}

Beberapa majas perbandingan yang digunakan pada puisi Hening Gendis, salah satunya adalah yaitu majas simbolik:

"Hening adalah ketika jarum-jarum jam dinding merapat ke angka XII dan menudingku, dan membentakku, dan mendorongku ke sudut, dan menampar-nampar pipiku, dan memelototkan mata dan bertanya keras-keras, ini jam berapa?." (Perihal Gendis: 15)

Data diatas dikategorikan sebagai majas simbol suasana. Penyair menggambarkan suasana mencekam dengan mennggunakan kata "Menudingku, dan membentakku, dan mendorongku ke sudut, dan menampar-nampar pipiku, dan memelototkan mata dan bertanya keraskeras, ini jam berapa?" Sehingga suasana yang ditimbulkan yaitu suasana mencekam dan ketakutan dari tokoh Gendis.

Pada puisi Duduk di Teras Belakang Waktu Bulan Purnama menggunakan majas yang bervariasi. Beberapa majas yang digunakan adalah aferesis, anafora, epifora, epizeuksis, simploke, metaora, personifikasi, simile, dan simbolik. Berikut adalah penjelasan mengenai majas yang terdapat dalam puisi Duduk di Teras Belakang Waktu Bulan Purnama:

\section{Majas Penegasan}

Pada puisi Duduk di Teras Belakang Rumah Waktu Bulan Purnama terdapat 2 majas aferesis, salah satunya yaitu:

"Apa gerangan yang membebani hatimu, bulan?" (Perihal Gendis: 20)

Majas yang digunakan dalam puisi diatas adalah majas aferesis. Penyair menghilangkan suku kata awal dalam kata

BASASTRA Jurnal Bahasa, Sastra, dan Pengajarannya 
hatimu. "Mu" yang digunakan pada akhir suku kata berasal dari kata dasar kamu.

\section{Majas Perbandingan}

Beberapa majas perbandingan yang digunakan pada puisi Duduk di Teras Belakang Waktu Bulan Purnama salah satunya yaitu majas metafora. Berikut adalah penjelasannya:

"Bulan sangat letih meski putih tetap menyiarkan keelokannya." (Perihal Gendis: 20)

Data diatas merupakan majas metafora. Penyair menggunakan kata menyiarkan keeolokannya. Menyiarkan keelokannya mempunyai arti memancarkan sinar dari bulan.

Puisi Konon menggunakan majas yang bervariasi. Beberapa majas yang digunakan adalah anafora, pleonasme, aferesis, metafora, personifikasi, simile, dan simbolik. Berikut adalah penjelasan mengenai majas yang terdapat dalam puisi Konon:

\section{Majas Penegasan}

Beberapa majas penegasan yang digunakan pada puisi Konon salah satu majas yang digunakan yaitu majas pleonasme yang berjumlah 2. Berikut penjelasannya"

"Ia ingin jadi buah apel yang krowak. "(Perihal Gendis: 35)

Data diatas termasuk dalam majas pleonasme. Penyair menggunakan kata yang tidak efektif yaitu buah apel. Penyair dapat menggunakan apel saja tanpa menambahkan buah. Karena apel sudah pasti termasuk salah satu jenis buah.

\section{Majas Perbandingan}

Beberapa majas Perbandingan yang digunakan pada puisi Konon, salah satunya yaitu personifikasi yang berjumlah 3 majas. Berikut penjelasannya:

"Konon kasih sayang itu seperti bola ping-pong yang kuning, yang putih, dismes siang-malam melewati malam melewati net. Dipelintir siang malam menyentuh meja." (Perihal Gendis: 35)

Kasih sayang yang merupakan perasaan seseorang dianggap dapat dieprlintir oleh siang dan malam. Penyair menggambarkan kasih sayang yang penuh seperti siang dan malam. Sehingga data diatas dapat dikategorikan sebagai majas personifikasi.

Puisi Langit-langit

menggunakan majas yang bervariasi. Beberapa majas yang digunakan adalah anafora, epifora, pleonasme, simploke, retoris, elipsis, metafora, personifikasi, simile, onomatope, hiperbola, dan simbolik. Berikut adalah penjelasan mengenai majas yang terdapat dalam puisi Langit-langit:

\section{Majas Penegasan}

Beberapa majas penegasan yang digunakan pada puisi Langit-langit, salah satunya adalah simploke yang berjumlah 1 majas. Berikut adalah penjelasannya:

"Disinipun aku bisa menangis, bukan? Sekarangpun aku bisa menangis, bukan? Sekarang pun aku sedang menangis, bukan?" (Perihal Gendis: 51)

Penyair menggunakan majas simploke dalam puisi diatas. Kata menangis, bukan? Yang terletak pada akhir kalimat diulang 3 kali secara berurutan. Majas simploke dalam puisi diatas digunaka untuk mempertegas Gendis yang sedang menangis. Selain itu, majas simploke digunaka untuk nilai estetis penulis.

\section{Majas Perbandingan}

Beberapa majas perbandingan yang digunakan pada puisi Langit-langit, salah satunya yaitu majas hiperbola yang terdapat 2 majas. Berikut penjelasannya:

"Tampak seperti mata yang sudah sangat lama terpejam di sudut kiri otaknya." (Perihal Gendis: 52)

Majas hiperbola terdapat dalam penggala puisi diatas. Terdapat kata sudah sangat lama yang mempunyai arti berlebihan.

Pada puisi Tak Perlu menggunakan majas metafora. Berikut adalah penjelasan mengenai majas yang terdapat dalam puisi Tak Perlu:

\section{Majas Perbandingan}

Pada puisi Tak Perlu terdapat 1 majas metafora, salah satunya yaitu: 
"Aku ingin ke barat sendiri saja membelakangi bukit Timur sarang matahari pagi itu." (Perihal Gendis: 55)

Data diatas dapat dikategorikan sebagai majas metafora. Penyair menggunaka kata sarang matahari pagi itu. Sarang matahari yang dimaksud adalah matahari yang terbit pada pagi hari dari ufuk timur.

\section{Citraan dalam Buku Kumpulan Puisi Perihal Gendis Karya Sapardi Djoko Damono}

Dalam buku kumpulan puisi Perihal Gendis ditemukan beberapa penggunaa citraan. Citraan digunakan penyair untuk membangun emosi seakan-akan pembaca merasakan dan membayangkan apa yang ingin disamapikan oleh penyair. citraan dapat dibagi menjadi lima, yaitu: (a) citraan penglihatan (visual), (b) citraan pendengaran (auditoris), (c) citraan gerak (kinestatik), (d) citraan rabaan (taktil termail), (e) citraan penciuman (olfaktori) dan (f) pengecapan (Nurgiyantoro: 2013: 411). Berikut adalah hasil penelitian citraan yang terdapat dalam puisi Percakapan di Luar Suara Riuh, Hening Gendis, Duduk di Teras Belakang Rumah Waktu Bulan Purnama, Konon, Langitlangit, dan Tak Perlu. Berikut penjelasannya:

\section{Citraan Penglihatan}

"Hei lihat mawar itu!" (Perihal Gendis: 1)

Data diatas menggunakan citraan penglihatan karena penyair memberi gambaran kepada pembaca untuk melihat bunga mawar. Seolah pembaca ikut melihat mawar yang ditunjuk oleh Gendis.

\section{Citraan Pendengaran}

"Hening adalah ketika terdengar dendang gerimis." (Perihal Gendis: 13)

Terdapat citraan pendengaran dalam puisi diatas. Penyair menggunakan kata "terdengar dendang gerimis" seolah-olah pembca membayangkan suara gerimis yang dapat ditangkap oleh indra pendengaran.

\section{Citraan Gerak}

"Ia berjongkok di rerumputan memungut sebutir kristal." (Perihal Gendis: 21)

Terdapat kata "memungut kristal" yang dapat dikategorikan sebagai citraan gerak karena memberkan gambaran memungut kristal. Memungut kristal merupakan aktivtas gerak.

Citraan Perabaan

"Ingin menjadi telor yang lonjong dan halus sempurna kulitnya" (Perihal Gendis: 38)

Data diatas termasuk citraan perabaan. "Halus sempurna" menggambarkan telur yang permukaannya kulitnya halus yang dapat diraba kemudian dibayangkan oleh pembaca.

\section{Citraan Penciuman}

"Baumu amis!" (Perihal Gendis: 47).

Bau amis merupakan kata yang membuat pembaca seolah-olah membayangka bau amis/bau tidak sedap. Pembaca akan mengimajinasikan bau amis sehingga dapat masuk dala citraan penciuman. (Perihal Gendis: 47).

\section{Citraan Pengecapan}

"Aku mata aku telinga aku lidah yang melihat yang mendengar yang mencecap." (Perihal Gendis: 48)

Data diatas termasuk dalam citraan pengecap. Penyair menggunakan kata "mencecap", yaitu aktivitas lidah menjilat dan mencecap sesuatu untuk mengetahui rasaya untuk membuat membaca seolaholah mencecap sesuatu.

\section{Nilai Pendidikan Karakter dalam Buku Kumpulan Puisi Perihal Gendis Karya Sapardi Djoko Damono}

Nilai pendidikan karakter menurut Naim (2012: 123-212) adalah: jujur, religius, toleransi, disiplin, kerja keras, kreatif, mandiri, demokratis, rasa ingin tahu, semangat kebangsaan, cinta tanah ar, menghargai prestasi, bersahabat, cinta 
damai, gemar membaca, peduli sosial, peduli lingkungan, dan tanggug jawab. Berikut adalah penjabaran mengenai 5 nilai pendidikan karakter dalam kumpulan puisi Perihal Gendis karya Sapardi Djoko Damono:

\section{Rasa Ingin Tahu}

Rasa ingin tahu adalah perasaan ingin tahu seseorang secara mendalam terhadap suatu hal. Dalam kumpulan puisi Perihal Gendis penyair menyampaikan tokoh Gendis yang memiliki rasa ingin tahu terhadap apapun yang ada di sekelilingnya.

Gendis digambarkan sebagai gadis remaja yang kesepian karena ditinggal oleh orang tuanya. Karena kesepian, Gendis mengajak berbicara makhluk hidup yang ada di sekitarnya. Misalnya saja kupukupu, mawar, burung, dan ulat. Gendis menanyakan kemana perginya kupu-kupu dan pasangannya.

\section{Peduli Sosial}

Peduli sosial merupakan kepekaan mengenai segala kesulitan yang ada di lingkungan dan masyarakat. Mas Robin digambarkan oleh penyair sebagai satpam kompleks yang selalu membawa gendewa. Selain itu, Mas Robin juga bertugas untuk mengumpulkan dana dari orang-orag kompleks untuk dibagikan pada orangorang yang membutuhkan. Hal tersebut merupakan salah satu bentuk kepedulian terhadap sesama manusia.

\section{Kerja Keras}

Kerja keras adalah upaya sungguhsungguh untuk menyelesaikan hambatan yang terjadi untuk menyelesaika tugas dengan sebaik-baiknya. Penyair menggambarkan nilai pendidikan karakter dalam kumpulan puisi Perihal Gendis terdapat dalam puisi yang berjudul Dongeng Kakek. Puisi tersebut menceritakan seorang kakek yang sudah ke sawah untuk mencangkul sejak matahari terbit. Walaupun sudah tua dan sakitsakitan, kakek tersebut tetap bekerja keras dengan menjadi petani dan bekerja keras dari pagi untuk memenuhi kebutuha sehari-hari. Penyair dalam menciptakan karya sastranya juga harus menyisipkan nilai-nilai yang akan diteladani oleh pembaca.

\section{Religius}

Religius merupakan adalah perilaku memegang teguh perintah agama dan menjauhi larangannya, saling menjaga kerukunan dan kesatuan walaupun berbeda keyakinan. Dalam buku kumpulan puisi Perihal Gendis karya Sapardi Djoko Damono, terdapat nilai pendidikan karakter religius dalam puisi yang berjudul Hening Gendis.

\section{Peduli Lingkungan}

Peduli Lingkungan merupakan melestarikan alam yang ada di sekitarnya. Buka hanya alam, namun juga lingkugan keluarga, rumah, sekolah, dan lain-lain. Pendidikan karakter peduli lingkungan dalam kumpulan Puisi Perihal Gendis ditunjukkan oleh karakter Gendis. Gendis digambarkan memiliki sifat peduli lingkungan. Sifat tersebut berawal dari rumah Gendis yang terlihat kotor dan berantakan. Hal tersebut terdapat dalam puisi yang berjudul Apa Sebaiknya Aku Tak Bermimpi Lagi:

\section{Relevansi Buku Kumpulan Puisi Perihal Gendis karya Sapardi Djoko Damono Sebagai Materi Pembelajaran Satra}

Guru yang baik memerhatikan kelengkapan perangkat pembelajaran mulai dari perencanaan hingga evaluasi. RPP dan silabus merupakan komponen pembelajaran yang dibuat dari awal hingga akhir tahun pembelajaran oleh guru. Dalam RPP terhadap komponen-komponen yang menjadi tolak ukur keberhasilan guru dalam melakukan pembelajaran dalam suatu kelas.

Komponen yang harus diperhatikan oleh guru dalam melaksanakan pembelajaran di kelas adalah RPP dan Silabus. Materi yang digunakan oleh guru haruslah sesuai dengan Kompetensi Dasar 
yang hendak dicapai oleh guru. Materi pembelajaran yang dipakai dalam penelitian ini menggunakan kurikulum 2013 di SMA yang sudah diberlakukan. Penelitian ini menggunakan materi tentang puisi yang diajarkan pada kelas $\mathrm{X}$ semester genap.

\section{Kompetensi Inti Pengetahuan (K13)}

3.16 Mengidentifikasikan suasana, tema, dan makna beberapa puisi yang terkandung dalam antologi puisi yang diperdengarkan atau dibaca

3.17 Menganalisis unsur pembangun puisi

Kompetensi Inti Keterampilan (K14)

4.16

Mendemonstrasikan (membacakan atau memusikalisasikan) satu puisi dari antologi puisi atau kumpulan puisi dengan memerhatikan vokal, ekspresi, dan intonasi (tekanan dinamik dan tekanan tempo)).

4.17 Menulis puisi dengan memerhatika unsur pembangunnya

Data diatas merupakan Kompetensi Dasar mengenai puisi yang diajarkan pada kelas $\mathrm{X}$ jenjang SMA. Materi pembelajaran harus disiapkan sesuai dengan kurikulum dan menyesuaikan dengan kebutuhan siswa, Kompetensi Dasar, dan Indokatornya agar terciptanya tujuan pendidikan nasional.

Bahan ajar yang baik dapat menarik siswa sehingga mempermudah penyampaikan materi yang akan diajarkan kepada siswa. Bahan ajar tersebut harus kontektekstual dan membuat peserta didik lebih aktif dan tertarik seperti yang telah diamanatkan oleh kurikulum. Materi pembelajaran yang dipilih haruslah dipikirkan dengan matang agar terciptanya pembelajaran yang lancar dan berkualitas. Buku terbitan Kemendikbud menjadi buku utama yang digunakan guru dalam proses pembelajaran. Namun, guru dapat menambah sumber referensi lain untuk menunjang pembelajaran. Misalnya saja buku dari penerbit swasta atau buku kumpulan puisi karya sastrawan. Seperti kumpulan puisi Sapardi Djoko Damono, Herman J Waluyo, Joko Anwar, dan lainlain.

Kumpulan puisi Perihal Gendis karya Sapardi Djoko Damono sudah sesuai dengan komponen dan aspek yang sesuai dengan syarat yang ditetapkan oleh BSNP. Sehingga kumpulan puisi Perihal Gndis dapat dijadikan sebagai materi pembelajaran menulis puisi kelas $\mathrm{X}$ di Sekolah Menengah Atas. Materi dan isi yang disajikan tidak mengandung unsur SARA dan sesuai dengan tujuan pendidika nasional, buku disajikan dengan baik dan layak sebagai referensi pembelajaran, tidak menggunaka bahasa yang vulgar dan menggunakan bahasa komunikatif, dan menggunaka kegrafikaan yang membuat siswa lebih jelas dalam memahami materi.

Kumpulan puisi Perihal Gendis karya Sapardi Djoko dapat dipertimbangkan sebagai bahan ajar karena sesuai dengan KD 3.16, 4.16, 3.17, dan 4.17 di kelas $X$ tentang puisi. Kompetensi Dasar tersebut menggunakan puisi sebagai materi ajar. Kumpulan puisi Perihal Gendis karya Sapardi Djoko Damono kaya akan diksi, gaya bahasa, citraan, dan nilai pendidikan karakter sehingga akan memperkaya kosa kata dan menambah wawasan siswa. Oleh karena itu, puisipuisi dalam kumpulan puisi Perihal Gendis karya Sapardi Djoko Damono dapat dijadikan sebagai referensi dalam pembelajaran menulis puisi siswa kelas $\mathrm{X}$ di Sekolah Menengah Atas. Hal tersebut diperkuat dengan adanya pendapat dari berbagai informan yang diwawancarai dan berpendapat bahwa puisi-puisi yang terdapat dalam kumpulan puisi Perihal Gendis karya Sapardi Djoko Damono relevan sebagai bahan ajar menulis puisi di Sekolah Menengah Atas. 


\section{SIMPULAN}

Diksi bermakna konotatif lebih dominan daripada diksi bermakna denotatif pada buku kumpulan puisi Perihal Gendis karya Sapardi Djoko Damono. Enam puisi yang dianalisis lebih dominan diksi bermakna konotatif daripada denotatif. Ditemukan 12 data bermakna denotatif dan 43 data bermakna konotatif. Jika dipresentasikan maka terdapat 21,8\% makna denotatif dan $78,1 \%$ makna konotatif.

Bahasa figuratif yang terdapat dalam buku kumpulan puisi Perihal Gendis karya Sapardi Djoko Damono cukup banyak dan bermacam-macam. Ditemukan majas yang paling dominan tiga teratas yaitu anafora, kemudian personifikasi, kemdian simbolik. Ditemukan 23 data dengan presentase $23,71 \%$ majas anafora, 17 data dengan presentase 17,5 majas personifikasi, dan 13 data dengan presentase 13,4 majas simbolik.

Dalam buku kumpulan puisi Perihal Gendis karya Sapardi Djoko Damono ditemukan penggunaan citraan yang bervariasi. Citraan yang paling dominan adalah gerak yaitu 32 data dengan

\section{REFERENSI}

Keraf, G. (2004). Diksi dan Gaya Bahasa. Jakarta: PT Gramedia Pustaka Utama

Kosasih, E. (2015). Tata Bahasa dan Sastra Indonesia. Bandung: Yrama Widya

Pradopo, R.D. (2012). Pengkajian Puisi. Yogyakarta: Gadjah Mada University Press

Lestari, Y. W., Sumarwati, \& Mujiyanto, Y. (2017). Kajian Stilistika Kumpulan Puisi Asal Muasal Pelukan Karya Candra Malik Sebagai Materi Ajar Bahasa Indonesia di Sekolah Menengah Atas, Basastra: Jurnal Pengajaran Bahasa, Sastra, dan Pengajarannya, 5(2) 23-24 presentase $32,3 \%$, kemudian penglihatan yaitu 31 data dengan presentase $31,3 \%$, pendengaran yaitu 25 data dengan presentase $25,2 \%$, penciuman yaitu 8 data dengan presentase $8 \%$, perabaan yaitu 2 data dengan presentase $2 \%$, dan yang paling jarang yaitu citraan kecap yaitu 1 data dengan presentase $1 \%$,

Buku kumpulan puisi Perihal Gendis karya Sapardi Djoko Damono terdapat lima nilai pendidika karakter. Berdasarkan hasil penelitian, nilai-nilai pendidikan karakter yang terdapat dalam buku kumpulan puisi Perihal Gendis adalah rasa ingin tahu, peduli sosial, kerja keras, religius, dan peduli lingkungan. Nilai pendidikan karakter yang paling dominan dalam buku kumpulan puisi tersebut adalah rasa ingin tahu.

Buku kumpulan puisi Perihal Gendis karya Sapardi Djoko Damono dapat dipertimbangakan sebagai bahan ajar sastra di SMA khususnya pada materi mengenai puisi atau menulis puisi. Buku puisi tersebut disesuaikan dengan kriteria yang ditetapkan oleh BSNP (Badan Standar Pendidikan Nasional.

Nurgiyantoro, B. (2013). Teori Pengkajian Fiksi. Jogjakarta: Gadjah Mada University Press

Naim, N. (2012). Character Building. Yogyakarta: Ar-Ruzz Media

Ratna, N.K. (2016). Stilistika Kajian Pustaka Bahasa, Sastra, dan Budaya. Yogyakarta: Pustaka Belajar

Satoto, S. (2012). Stilistika. Yogyakarta: Penerbit Ombak

Waluyo, H.J. (2003). Apresiasi Puisi. Jakarta: Gramedia Pusaka Utama.

(1995). Teori dan Apresiasi Puisi. Jakarta: Penerbit Erlangga 